\title{
Looking Forward Looking Back: \\ Customary International Law, Human Rights and Indigenous Peoples
}

\author{
Shea Esterling*
}

\begin{abstract}
Two of the most laudable achievements of human rights are the 1948 Universal Declaration of Human Rights (UDHR) and the 2007 United Nations Declaration on the Rights of Indigenous Peoples (UNDRIP). Aside from advancing human rights, both are examples of soft law. For the UNDRIP, this soft law status has generated significant controversy which is evocative of the earlier debate surrounding the legal status of the UDHR. Yet unexamined, this article analyses this contemporary controversy surrounding the UNDRIP in light of the historical debate surrounding the legal status of the UDHR. Fleshing out points of convergence and divergence, these debates unearth narratives which shed light on the claims and advocacy strategies of Indigenous Peoples and the role of customary international law within human rights. Ultimately, it reveals that these narratives do little to secure the enforcement of indigenous rights.
\end{abstract}

Key words

Universal Declaration of Human Rights, United Nations Declaration on the Rights of Indigenous Peoples, customary international law, Indigenous Peoples

\section{Introduction}

Two of the most laudable achievements in the post-war effort to maintain international peace and security are the 1948 Universal Declaration of Human Rights (UDHR) ${ }^{1}$ and the 2007 United Nations Declaration on the Rights of Indigenous Peoples (UNDRIP). ${ }^{2}$ The former, as the name suggests, is an explication of rights applicable to all while the latter provides sui generis protection for the rights of Indigenous Peoples and is the pinnacle of the discrete human rights' framework for the promotion and protection of indigenous rights. Both present significant advancements in the promotion and protection of human rights. Moreover, as sources of international law, both are examples of soft law and as such are distinguishable from hard law such as treaties and customary international law (CIL). For the UNDRIP, this status as soft law is a thorny issue that generates significant controversy; a controversy which is evocative of an earlier debate in international human rights law (IHRL) surrounding the UDHR and its status as CIL.

Yet unexamined, this article analyses the contemporary controversy surrounding the legal status of the UNDRIP in light of the historical debate surrounding the legal status of the

\footnotetext{
*Senior Lecturer and Early Career Researcher; University of Canterbury School of Law, New Zealand. Email: shea.esterling@canterbury.ac.nz

This article appears as: S. Esterling, Looking Forward, Looking Back: Customary International Law, Human Rights and Indigenous Peoples, 28 International Journal on Minority and Group Rights 1 (2021) 1-26 (Brill).

${ }^{1}$ Universal Declaration of Human Rights, GA Res. 217A (III) UN GAOR, 3d Sess., UN Doc. A/810 (1948) at (hereinafter UDHR).

${ }^{2}$ United Nations Declaration of the Rights of Indigenous Peoples, GA Res. 61/295, UN GAOR, $61^{\text {st }}$ Sess. $107^{\text {th }}$ Plen. Mtg., UN Doc. A/Res/61/295 (13 September 2007) (hereinafter UNDRIP).
} 
UDHR. Fleshing out points of convergence and divergence, these debates unearth narratives which shed light on the claims and advocacy strategies of Indigenous Peoples and CIL within IHRL as the predominate moral paradigm of the late twentieth and early twenty-first centuries. As regards CIL, it argues that outside the walls of the Palais de Nations there is widespread emancipatory fervour on the part of international lawyers. This has meant some of the most basic elements of CIL have been either cast aside or so dramatically altered that it is unrecognizable; "all-in-all, the intellectual prison of custom seems to be gradually transformed into a large dancefloor where (almost) every step and movement is allowed, or, at least, tolerated". ${ }^{3}$ As regards the claims and advocacy strategies of Indigenous Peoples, it argues that although a discrete space for the promotion and protection of indigenous rights has been carved out, the claims and strategies to secure this space both replicate and extend the UDHR narrative. In doing so, these claims and strategies having varying trajectories. In replicating the CIL narrative, indigenous claims and strategies continue to do violence to CIL and the very foundations of international law; while in extending this narrative they ultimately reflect the essentializing propensity of IHRL. Ultimately however, both narratives do little to secure the enforcement of indigenous rights.

This article proceeds as follows. First, it lays the foundations for such an inquiry by briefly detailing the development of the UDHR and the UNDRIP as well as the concepts crucial to the sources of international law discourse. With the foundation laid, this article then unearths the narratives that have been developed in relation to each of these declarations regarding their legal status. It analyses these narratives as well as the critiques of these narratives. In doing so, it builds on the work of Bruno Simma and Phillip Alston in relation to the UDHR ${ }^{4}$ to reveal points of convergence and divergence which ultimately offers insight into the role that indigenous claims, indigenous advocacy and CIL play in relation to each other and within IHRL as the lingua franca of rights protection.

\section{The Declarations and the Sources of International Law}

\subsection{The Universal Declaration of Human Rights, 1948 (UDHR)}

In 1946, the Economic and Social Council of the newly established United Nations (UN) created the Commission on Human Rights. Comprised of nine members under the leadership of Eleanor Roosevelt, the Commission met in early 1947 and at its first session recommended drafting a document for the protection of human rights. It was agreed that work would commence on two documents: a draft bill of rights in the form of a declaration and a draft convention containing a bill of rights eventually to be submitted to states for ratification. After numerous meetings, the former was achieved on 10 December 1948 when the UDHR was adopted by the General Assembly (GA) of the UN with 48 votes in favour, none against and eights abstentions including South Africa, Saudi Arabia and the Soviet bloc states.

Motivated by the experiences of the preceding world wars, the UDHR was the first time that countries agreed on a comprehensive statement of inalienable human rights. It opens with recognition that "the inherent dignity of all members of the human family is the foundation of

\footnotetext{
${ }^{3}$ J. d'Aspremont, 'Customary International Law as a Dance Floor: Part 1', ejiltalk.org, available at <www.ejiltalk.org/customary-international-law-as-a-dance-floor-part-i/>, visited 14 April 2014.

${ }^{4}$ See B. Simma and P. Alston, 'The Sources of Human Rights Law: Custom, Jus Cogens and General Principles', 12 Australian Year Book of International Law (1992).
} 
freedom, justice and peace in the world". ${ }^{5}$ As the name suggests, it is rooted in the ethos that human rights are universal: to be enjoyed by all people, no matter who they are or where they live. Aside from universality, it also espouses the concepts of dignity, equality, inalienability and non-discrimination which provide the normative foundations of modern IHRL declaring that "all human beings are born free and equal in dignity and rights". 6 Together with the International Covenant on Civil and Political Rights ${ }^{7}$ and the International Covenant on Economic, Social and Cultural Rights, ${ }^{8}$ these documents are collectively known as the International Bill of Rights and are hailed as the crowning achievement of the UN for the promotion and protection of human rights through IHRL.

\subsection{The United Nations Declaration on the Rights of Indigenous Peoples, 2007 (UNDRIP)}

Despite the achievements of the UDHR and the International Bill of Rights, they did little to address directly the plight of Indigenous Peoples at the hands of colonialism. However, over the last 40 years Indigenous Peoples ${ }^{9}$ have played a significant role in international lawmaking which has paralleled more broadly an increasing trend in the participation of nonstate actors in international fora. ${ }^{10}$ This emergence of Indigenous Peoples as non-state actors has centred upon efforts in the UN to produce a declaration on the rights of Indigenous Peoples. Established in 1982, the UN Working Group on Indigenous Populations (WGIP), a working group of the then Sub-Commission on Prevention of Discrimination and Protection of Minorities, ${ }^{11}$ began the lengthy drafting of the UNDRIP in 1985. After eight years, the WGIP agreed on the final text of the Draft Declaration which was adopted by the SubCommission in 1994 and proceeded to the then Commission on Human Rights. ${ }^{12}$ As states did not actively participate in the WGIP, the Draft Declaration reflected the aspirations of Indigenous Peoples and so it was unsurprising that the Commission comprised of state representatives had serious concerns over issues related to self-determination and control over natural resources and traditional lands. Therefore, instead of agreeing a proposed text, the Commission on Human Rights urged the establishment of another working group to further detail the declaration.

Consequently, the Working Group on the Draft Declaration (WGDD) was born as a mechanism to facilitate the meeting of states and Indigenous People to negotiate a text. ${ }^{13}$ Over 10 years after its establishment, the WGDD adopted the declaration and forwarded it to the newly established Human Rights Council which replaced the Commission on Human Rights. The Council adopted the declaration on 29 June 2006 at its first session with 30 in

\footnotetext{
${ }^{5}$ UDHR, supra note 1, Preamble.

${ }^{6} I d$. at Art. 1.

${ }^{7}$ International Covenant on Civil and Political Rights, GA Res. 2200A (XXI), 21 UN GAOR Supp. (No. 16) at 52, UN Doc. A/6316 (1966), 999 UNTS 171, entered into force 23 March 1976.

${ }^{8}$ International Covenant on Economic, Social and Cultural Rights, GA Res. 2200 (XXI), UN GAOR, 21 ${ }^{\text {st }}$ Sess., Supp. No. 16, UN Doc. A/6316 (1966), 993 UNTS 3, at Arts. 1, 3, 6, 15 entered into force 3 January 1976.

${ }^{9}$ See K. Engle, The Elusive Promise of Indigenous Development: Rights, Culture, Strategy (Durham: Duke University Press, 2010) (tracing indigenous participation in international law since the 1970s).

${ }^{10}$ See A. Boyle and C. Chinkin, The Making of International Law (Oxford: OUP, 2007).

${ }^{11}$ UN Doc. E/CN.4/Sub.2/1985/22, Annex II (27 August 1985). In 1999 the Sub-Commission on Prevention of Discrimination and Protection of Minorities was renamed the Sub-Commission on the Promotion and Protection of Human Rights.

${ }^{12}$ United Nations, Technical Review of the United Nations Draft Declaration on the Rights of Indigenous Peoples, UN Doc. E/CN.4/Sub.2/1994/(26 August 1994).

${ }^{13}$ United Nations Comm. Res. 1995/32, UN Doc. E/CN.4/RES/1995/32 (3 March 1995).
} 
favour, two against and 12 abstentions; it was then submitted to the UN GA. ${ }^{14}$ Given that the Human Rights Council offered its support for this draft of the declaration, it was expected that it would be adopted by the GA at the start of its $61^{\text {st }}$ session in November 2006.

However, the Third Committee of the GA (the Social, Humanitarian and Cultural Committee) voted to defer action on the declaration citing that it wanted to offer further time for consideration. ${ }^{15}$ Finally, however, the fruit of these efforts was borne out in the adoption of the UNDRIP by the GA in September 2007. Of the states in attendance, 143 voted in favour, 11 abstained and four voted against, namely Australia, Canada, New Zealand and the US. Also known as the CANZUS group, these settler states all noted that the UNDRIP was not binding and further Australia, Canada and the US explicitly highlighted that it did not reflect CIL. ${ }^{16}$

The overarching agenda of the UNDRIP focuses on promoting and protecting the distinctiveness of Indigenous Peoples in light of the shared historical and on-going wrongs that they have suffered at the hands of dominant society which are typically rooted in programs of discrimination and marginalization. In addressing such wrongs and providing redress, it is emphasized that the UNDRIP is understood to represent the "minimum standards" necessary for the "survival, dignity and well-being of the indigenous peoples of the world" 17 and therefore does not seek to privilege Indigenous Peoples but to ensure their equality with other peoples. ${ }^{18}$ It is as a mechanism "to fill a crucial gap" and "to guarantee coherence" to IHRL which is typified by different approaches to indigenous claims and rights. ${ }^{19}$ It consists of 45 articles and can be roughly divided into the following topics: selfdetermination; religious, cultural and linguistic rights; education and labour rights; rights to development and democracy; and land and resource rights.

\subsection{Customary International Law (CIL)}

The UDHR and the UNDRIP both have developed narratives regarding their legal status within the broader discourse of the recognized sources of international law. The starting point for the examination of sources of international law is Article 38 of the International Court of Justice (ICJ) Statute which lists the following as sources:

a. international conventions, whether general or particular, establishing rules expressly recognized by the contesting states;

b. international custom, as evidence of a general practice accepted as law;

c. the general principles of law recognized by civilized nations;

\footnotetext{
${ }^{14}$ United Nations, Human Rights Council Resolution 2006/2 (29 June 2006).

15 This deferment came as a response to an amendment proposed by the African Group of States suggesting that the General Assembly "defer consideration and action on the United Nations Declaration on the Rights of Indigenous Peoples to allow time for further consultations thereon". UN Doc. A/C.3/61/L.18/Rev.1 21 November 2006, A/C.3/61/L.57/Rev.1

${ }^{16}$ See generally Honourable R. Hill, 'Explanation of Vote by the Hon. Robert Hill, Ambassador and Permanent Representative of Australia to the United Nations' (speech, United Nations, New York, 13 September 2007); J. McNee, 'Statement by Ambassador McNee to the General Assembly on the Declaration on the Rights of Indigenous Peoples' (speech, United Nations, New York, 13 September 2007); United States Mission to the United Nations, 'Observations of the United States with Respect to the Declaration on the Rights of Indigenous Peoples' (news release, New York, 13 September 2007). Since this initial rejection these states have issued statements of support for the UNDRIP.

${ }^{17}$ UNDRIP, supra note 2, Art. 43.

${ }^{18}$ UNDRIP, supra note 2, Preamble para. 2

${ }^{19}$ M. Barelli, 'The Role of Soft Law in the International Legal System: The Case of the United Nations Declaration on the Rights of Indigenous Peoples', 58 International And Comparative Law Quarterly (2012) pp. 957, 959.
} 
d. ... judicial decisions and the teachings of the most highly qualified publicists of the various nations, as subsidiary means for the determination of rules of law. ${ }^{20}$

Recognized as formal sources of international law, these sources are known as hard law as they are legally binding. It is stressed within the relevant literature that this list is neither presented in a hierarchy nor is it exhaustive. In turn, Article 38 is deceptively simple and so has been subject to extensive criticism. ${ }^{21}$

Criticism aside, advocates of both the UDHR and the UNDRIP have developed narratives regarding their status within this discourse of the recognized sources of international law which seek to position the declarations as CIL. CIL is not a written source. A norm rises to the level of CIL when it satisfies a two-pronged test: first most countries must at least purport to follow the norm, and secondly they must do so out of a sense of legal duty or opinio juris. $^{22}$ In effect, CIL has two elements: widespread and consistent state practice, and the attainment of opinio juris, usually translated as a belief in legal obligation. As regards state practice, this component of CIL is touted as objective. It includes not just the practice of the government of a state but also of its courts and parliament. It includes what states say as well as what they do; therefore it can include things such as diplomatic acts, local public policy and what states do in or through international organizations. The practice can be a recent development or of long duration. The ICJ tells us in the North Sea Continental Shelf cases that:

\begin{abstract}
Although the passage of only a short period of time is not necessarily, or of itself, a bar to the formation of a new rule of customary international law on the basis of what was originally a purely conventional rule, an indispensable requirement would be that within the period in question, short though it might be, State practice, including that of States whose interests are specially affected, should have been both extensive and virtually uniform in the sense of the provision invoked; - and should moreover have occurred in such a way as to show a general recognition that a rule of law or legal obligation is involved..$^{23}$
\end{abstract}

Typically it is not required that a practice be universally followed, ${ }^{24}$ "but it should reflect wide acceptance among the states particularly involved in the relevant activity". ${ }^{25}$ Failure of a significant number of important states to adopt a practice can prevent a principle from becoming CIL.

The second prong for the formation of CIL is the subjective component. It maintains that even if a practice is widely followed, it will not constitute CIL if states feel legally free to disregard it. Thus, a practice followed merely as a matter of courtesy or habit is not CIL. Rather, the practice followed must be out of a sense that it is a legal obligation or opinio juris. This subjective component is identified by inductive reasoning where recurrent patterns of

\footnotetext{
${ }^{20}$ United Nations, Statute of the International Court of Justice, 3 Bevans 1179; 59 Stat. 1031; T.S. 993; 39 AJIL Supp. (1945) p. 215.

${ }^{21}$ See e.g. P. Malanczuk (ed.), Akehurst's Modern Introduction to International Law (Abingdon: Routledge, 7th edn, 1997) p. 1; G. Fitzmaurice, 'Some Problems Regarding the Formal Sources of International Law', in M. Koskenniemi (ed.), Sources of International Law (Abingdon: Routledge, 2000).

${ }^{22}$ See North Sea Continental Shelf, Germany v. Denmark, Merits, Judgment, (1969) ICJ Rep. 3, ICGJ 150 (ICJ 1969), 20 February 1969, International Court of Justice (ICJ), paras. 73-74.

${ }^{23} I d$., para. 74.

${ }^{24}$ See Case Military and Paramilitary Activities in and against Nicaragua (Nicaragua v. USA), Judgement of 27 June 1986, ICJ Reports 1986 (noting that completely uniform practice is not required for CIL to exist as long as instances of inconsistent state conduct are generally treated as breaches of the rule) at p. 14 para. 186.

25 Restatement (Third) of the Foreign Relations Law of the United States $\S 102$, Reporters' note b, (1987) (citations omitted).
} 
state practice are interpreted as flowing from juridical consideration. If the focus is on the deeds of states rather than words in this inductive process, the advantage is that the rules of CIL are solid as "they have been carefully hammered out on the anvil of actual, tangible interaction among States; and they allow reasonably reliable predictions as to future State behaviour". ${ }^{26}$

\title{
2. The Customary International Law Narrative: A Tale of Two Declarations
}

\subsection{UDHR and the Customary International Law Narrative}

The CIL narrative surrounding the UDHR was uncovered by Bruno Simma and Phillip Alston in their seminal 1992 article 'The Sources of Human Rights Law: Custom, Jus Cogens and General Principles'. ${ }^{27}$ This narrative was revealed as part of their broader enquiry into CIL and rests on the assertion that as IHRL expands its reach and scope, its potential ramifications increase and so does the need to ensure that its norms are firmly rooted in enforceable international law. ${ }^{28}$ Taking the UDHR as their example, they unearth an overarching narrative which seeks to place the declaration within CIL given the importance of human rights as an integral component of a just international order.

Indeed, the foundation of this challenge presented itself from the very outset. Upon adoption of the UDHR, Hersch Lauterpacht noted:

\begin{abstract}
The practical unanimity of the members of the United Nations in stressing the importance of the Declaration was accompanied by an equally general repudiation of the idea that the Declaration imposed upon them a legal obligation to respect human rights and fundamental freedoms which it proclaimed. The debate in the General Assembly and in the Third Committee did not reveal any sense of uneasiness on account of the incongruity between the proclamation of the universal character of the human rights forming the subject matter of the Declaration and the rejection of the legal duty to give effect to them. The delegates gloried on the profound significance of the achievement whereby the nations of the world agree as to what are the obvious and inalienable rights of man... but they declined to acknowledge them as part of the law binding upon their States and Governments. ${ }^{29}$
\end{abstract}

The subsequent account surrounding the status of the UDHR as CIL takes three different forms. First, Simma and Alston identify a narrative which flatly states that the entire corpus of IHRL meaning the substance of the UDHR is now to be regarded as CIL in its totality. ${ }^{30}$ The second narrative, is that the totality of the UDHR can be considered CIL if a "modernized view of customary international law" is applied which offers that non-state actors can create CIL. ${ }^{31}$ The third narrative characterized by Simma and Alston as a more moderate "middle-of-the-road" view offers that there are certain "hard core" human rights obligations that exist as CIL. ${ }^{32}$

\footnotetext{
${ }^{26}$ Simma and Alston, supra note 4, p. 89.

${ }^{27}$ See generally Simma and Alston, supra note 4. Simma and Alston do not describe their work as an exploration of a 'customary law narrative'. I have developed and employed this concept for the purposes of the analysis herein.

${ }^{28}$ Id., p. 82.

${ }^{29}$ H. Lauterpacht, International Law and Human Rights (New York: Frederick A. Praeger

1950) p. 61, reprinted in Simma and Alston, supra note 4, p. 151.

${ }^{30}$ Id., p. 84.

${ }^{31} I d$.

${ }^{32}$ Id., p. 85.
} 
Characterizing this overarching narrative as being far from cautious, they quip that perhaps this has to do with the fact that "human rights lawyers are notoriously wishful thinkers". 33 Aside from human rights layers, Simma and Alston identify UN officials as well as a number of scholars including those of the New Haven School who promote this narrative. Regarding the latter, they identify the writings of Lung-Chu Chen, K.M.G. Nayar and John Humphrey in the 1970s and 1980s as scholars who propound the notion that the UDHR in its entirety has achieved the status of CIL. ${ }^{34}$ For the more nuanced narrative that cannot view CIL in its normal processes, Simma and Alston point to Alexandre Kiss who propounds the idea that "if a rule or principle is universally proclaimed and recognized, evidence of its violation is simply irrelevant". ${ }^{35}$ Simma and Alston identify the most sophisticated approach as that of Oscar Schachter who proposes to rely on different kinds of evidence in the human rights dialogue to confirm that the UDHR has attained the status of CIL. ${ }^{36}$ From here, Schachter continues and espouses what Simma and Alston refer to as the "middle-of-the-road" narrative which offers that while not all of the provisions of the UDHR constitute CIL, there are certain provisions which have achieved this status. ${ }^{37}$

\subsection{UNDRIP and the Customary International Law Narrative}

In 1962 the Office of Legal Affairs of the UN clarified, upon request of the Commission on Human Rights, that a declaration "is a formal and solemn instrument ... resorted to only in very rare cases relating to matters of major and lasting importance where maximum compliance is expected". ${ }^{38}$ Even higher compliance is expected when a declaration is linked to the UN Charter which the UNDRIP would demand given that its first preambular paragraph provides that it was "[g]uided by the purposes and principles of the Charter of the United Nations, and good faith in the fulfillment of the obligations assumed by States in accordance with the Charter". ${ }^{39}$ However, academics and advocates of indigenous rights did not leave things to chance in relation to the status of the UNDRIP. They have developed an overarching CIL narrative which takes a very similar approach to that of the UDHR in that this narrative comprises a number of different strands to ensure its status as CIL.

The first narrative takes the view that the UNDRIP's provisions reflect CIL and the UNDRIP simply strengthens this connection. Prominent proponents here include S. James Anaya and Siegfried Wiessner for whom the "language of rights is the language of law". 40 They also maintain a second narrative; even if the UNDRIP has not achieved the status of CIL in toto it is possible to identify a number of different provisions within the UNDRIP that have attained

\footnotetext{
${ }^{33} I d .$, p. 84 (citation omitted).

${ }^{34} I d$., p. 91 (citations omitted).

${ }^{35} I d$. p. 82.

${ }^{36} I d$., p. 92 (citations omitted).

${ }^{37} I d$., p. 93. Simma and Alston identify academics who take up Schachter's view including Richard Lillich and Theodor Meron. Id.

${ }^{38}$ S. Wiessner, 'The Cultural Rights of Indigenous Peoples: Achievements and Continuing Challenges', 22 European Journal of International Law (2011) pp. 121, 130 (citation omitted).

${ }^{39}$ See F. Lenzerini, 'Implementation of the UNDRIP Around the World: Achievements and Future Perspectives. The Outcome of the Work of the ILA Committee on the Implementation of the Rights of Indigenous Peoples', 23:1-2 International Journal of Human Rights (2019) pp. 51-62, 55.

${ }^{40} \mathrm{~S}$. Allen, 'Limits of the International Legal Project', in S. Allen and A. Xanthaki (eds.), Reflections on the UN Declaration on the Rights of Indigenous Peoples (Oxford: Hart, 2011) p. 230. See generally S.J. Anaya, Indigenous Peoples in International Law (2nd edn., 2004); S. Wiessner, 'Rights and Status of Indigenous Peoples: A Global Comparative and International Legal Analysis', 12 Harvard Human Rights Journal (1999) p. 57. See also International Law Association, Rights of Indigenous Peoples: First Report, Rio de Janeiro Conference (2008) p. 6.
} 
this status. Like the "middle-of-the-road" narrative above in relation to the UDHR, this approach also asserts that a number of rights included in the UNDRIP have already achieved the status of CIL. Consequently, like Schachter who proposes to rely on different kinds of evidence in the human rights dialogue to confirm that the UDHR has attained the status of CIL, Anaya argues that "interactive patterns around concrete events are not the only - or necessarily required - material elements constitutive of customary norms". ${ }^{41}$ In turn, Anaya suggests that states and other relevant actors aside from the state increasingly engage in dialogue which can bring about a convergence of understanding and expectation regarding rules that give weight to a version of Thomas Franck's pull towards compliance: "the idea that explicit communication among authoritative actors is a form of practice that may bring about a convergence of understanding and expectation that builds customary rules". ${ }^{42}$ For Anaya and Wiessner, the provisions that have attained the status of CIL include rights to "demarcation, ownership, development, control and the use of lands that they have traditionally owned or otherwise occupied and used". ${ }^{43}$

To address this situation, immediately after the passage of the UNDRIP, the International Law Association (ILA) appointed a committee to provide an Expert Commentary which would offer "authoritative clarification, elucidation and guidance in respect of the UNDRIP provisions, including their development, context and status in international law". ${ }^{44}$ Further, it was suggested that "the Commentary will reduce confusion and contention over the normative status of the UNDRIP provisions and indigenous rights in general". ${ }^{45}$ Led by Wiessner, the committee released its final report regarding this matter in 2012. The committee noted that it cannot yet be said on the whole that the UNDRIP can be considered a statement of existing CIL but that there are certain key provisions that can be considered as such. ${ }^{46}$ Amongst those indigenous rights that the committee identified as having achieved the status of CIL are: the right of self-determination, ${ }^{47}$ the right to autonomy or selfgovernment, ${ }^{48}$ the right to the restitution of ancestral lands in order to fulfil the rights of Indigenous Peoples to their traditional lands and territories, ${ }^{49}$ and lastly the right to reparation and redress for wrongs they have suffered, including rights relating to lands taken or damaged without their free, prior and informed consent. ${ }^{50}$ Subsequent to this report, proponents of indigenous rights argue that the rejection of indigenous rights as CIL is rooted in an epistemological misunderstanding of CIL.

The reluctance to recognize the existence of such rights under customary international [law] is indeed determined by the inaccurate belief that their recognition would imply an obligation for States to ensure the

\footnotetext{
${ }^{41}$ Anaya, supra note 40, p. 62.

${ }^{42}$ M. Davis, 'To Bind or Not to Bind: the United Nations Declaration on the Rights of Indigenous Peoples Five Years On', 19 Australian International Law Journal (2012) pp. 17, 42.

${ }^{43}$ Allen, supra note 40, p. 230. See generally S.J. Anaya and S. Wiessner, 'The UN Declaration on the Rights of Indigenous Peoples: Towards Re-empowerment', Jurist Forum, School of Law, University of Pittsburgh, 3

October 2007 p. 4, available at <jurist.law.pitt.edu/forum/2007/10/undeclaration-on-rights-of-Indigenous-php>; S.J. Anaya and R.A. Williams, 'The Protection of Indigenous Peoples Rights over Lands and Natural Resources under the Inter-American Human Rights System', 12 Harvard Human Rights Journal (1999) p. 57.

${ }^{44}$ International Law Association, Rights of Indigenous Peoples: First Report, Rio de Janeiro Conference (2008) p. 3.

45 Id.

${ }^{46}$ International Law Association, Conclusions and Recommendation of The Committee on the Rights of Indigenous Peoples, Resolution No. 5/2012, para. 2 (2012).

${ }^{47} I d$., para. 4.

${ }^{48} I d$. , para. 5.

${ }^{49} I d$., para. 7.

${ }^{50} I d$. , para. 9.
} 
realization of the rights in point in all circumstances - with no exception possible - irrespective of the implications, of whatever kind, arising from their operation. This would mean that all other values, even those which are fundamental for the national society of the State concerned, should be always and peremptorily sacrificed in the altar of indigenous peoples' rights. Obviously, this is not the real consequence arising from the affirmation of the fundamental rights of indigenous peoples as rules of customary international law. ${ }^{51}$

Lenzerini emphasizes that CIL does not create a peremptory obligation to fully comply without exception and highlights that when there is conflict, determination is to be made on a case by case basis; an approach he finds support for in the jurisprudence of the InterAmerican Court of Human Rights (IACtHR) as concerns Indigenous Peoples. ${ }^{52}$ The ultimate aim here is to make this particular CIL narrative more palatable to its opponents; namely states who are concerned with relinquishing control over situations which implicate indigenous rights.

\section{Convergence: Customary International Law \& Human Rights}

The overarching narratives of both the UDHR and the UNDRIP seek to place the declarations within CIL through one or more of the following parallel sub-narratives which can roughly be characterized as follows: the declaration simply has achieved customary status in toto, the totality of the declaration can be considered CIL if an altered view of CIL is applied, and finally certain provisions of the declaration can be considered CIL. Upon closer examination, a number of similarities between the UDHR and UNDRIP narratives emerge. At their core, these overarching CIL narratives are fuelled by the dichotomy between hard law and soft law and in particular the preference for the former over the latter. As noted, hard law is legally binding. By contrast, soft law refers to rules and instruments that do not have legally binding force but at the same time do not completely lack legal significance. Soft law is not a formal source of law in its own right, unlike the provisions listed in Article 38 of the ICJ Statute. Rather the term is mainly used to describe non-binding instruments that set standards and/or form part of the law-making process indicating the direction in which the law could develop in the future. Frequently cited examples of soft law include codes of conduct and declarations; especially those of the UN GA such as the UDHR and the UNDRIP.

It is this dichotomy between hard and soft law that underpins the CIL narrative developed by advocates of both the UDHR and the UNDRIP. In particular, their construction stems from the fact that as declarations both are soft law and as such are non-binding. Consequently, each narrative turns to the possibility of CIL as a means to transform and bolster the legal effect of the declaration. Although the lingua franca of rights protection ascribes increasing importance to soft law as a tool in the arsenal of human rights activists, including advocates for Indigenous Peoples in their campaign to protect and increase their rights, ${ }^{53}$ hard law remains the preference. Indeed, in a similar vein, elsewhere it is argued that principles of soft law included in declarations such as the UDHR and the UNDRIP can become the fons et origo or the origins of CIL. ${ }^{54}$ The ICJ has confirmed that they can crystallize into 'hard' or enforceable CIL in its advisory opinion on the Legality of Nuclear Weapons stating that,

\footnotetext{
${ }^{51}$ Lenzerini, supra note 39, p. 53.

${ }^{52}$ Id., pp. 53-54.

${ }^{53}$ See generally M. Barelli, supra note 19 (exploring the practical advantages of using soft law for Indigenous Peoples' rights arguing that it increased the value of the Declaration given the latter's character and content).

${ }^{54}$ See generally id. (also arguing that the UNDRIP has the potential to have legal effect through its development into hard customary and/or treaty law).
} 
"General Assembly resolutions, even if they are not binding, may ... provide evidence important for establishing the existence of a rule or the emergence of an opinion juris." $" 55$

With the essence of each narrative as a shared attempt to overcome this (perceived) limitation ${ }^{56}$ of soft law and to place the UDHR and the UNDRIP within the ambit of enforceable hard law via CIL, ultimately these narratives also both attest to the preference of human rights academics and advocates for the binding nature of hard law; and in particular the power of CIL as a tool in its construction. This further suggests that the lingua franca of human rights protection, including the protection of discrete indigenous rights, continues to recognize that treaty law alone is not enough under IHRL to ensure the generation of obligations. Consequently human rights uses these CIL narratives to fill in obligation gaps.

Finally, these narratives implicitly recognize that it is only through CIL that Indigenous Peoples as emerging non-state actors can wield powerful influence; specifically indigenous rights advocates are able to exercise influence in the creation and development of CIL in a way that they cannot in relation to treaty law. Although such an advantage may be principally rhetorical, the appearance of effective presentation is crucial in the quest for rights. ${ }^{57}$

Through this preference for hard law and the creation of obligations, human rights as the dominate dialogue of protection generates a space for the development of these narratives surrounding the UDHR and the UNDRIP which centre on CIL. This invites us to ask, why through CIL and why through human rights law? As regards the former, the answer lies in the vagaries of CIL. As regards the latter, the answer lies in the international legal project.

As previously mentioned, CIL has two elements: widespread and consistent state practice, and the attainment of opinio juris, usually translated as a belief in legal obligation. However, these two requirements are not as simple as they seem and belie the real vagaries of the formation of CIL. As for widespread, how much state practice is required to make manifest a new rule of CIL? How many states does it require for the formation of a new rule of CIL? And then we have questions à $l a$ all animals are equal but some are more equal than others: ${ }^{58}$ such as does the practice of some states count more than that of other states? If so, which states? In relation to all new rules of CIL or just certain rules of CIL? Depending on the subject matter or something else? As for consistent, do we tolerate any inconsistent state practice? If so how much? How long must the practice have continued for and what kind of practice counts to form a rule of CIL? These are just the questions in relation to the ostensibly simpler objective component of CIL regarding state practice. Things become much murkier when we enter the waters of the subjective element of opinion juris. What

\footnotetext{
${ }^{55}$ Legality of Nuclear Weapons, Advisory Opinion, ICJ Rep 1996, 226, para. 70

${ }^{56}$ Whether or not soft law is a limitation has its own narrative in the lingua franca of human rights. However, it is outside of the remit of this paper. In the context of the UNDRIP, Davies argues that to view it as such denies agency to Indigenous Peoples. Davis, supra note 42, p. 37. For instance, she suggests that there is agency in the strategic work of indigenous Peoples at the UN as "the choice of a soft law instrument for Indigenous peoples rights is one of many example where advocates of human rights and states negotiate the risks of non-ratification of hard law instruments with non-compliance with soft law”. Id., p. 39 (citation omitted).

57 Allen, supra note 40, p. 234.

${ }^{58}$ Inspired by George Orwell's Animal Farm and the Seven Commandments of Animalism, the most important of which is that: "[a]ll animals are equal". However, as the story progresses and the pigs begin to transform looking more and more like their former human overlords the commandment is morphs into "[a]ll animals are equal, but some animals are more equal than others". See G. Orwell, Animal Farm (Harcourt, Brace \& Co., New York, 1946).
} 
does it really mean to say that a state is acting out of a sense of legal obligation? Does it require belief that it is required by existing law or not? Indeed, there is an inherent circularity in these requirements: how can practice be based on a sense of legal obligation before it becomes law? This circularity makes the test for CIL very difficult to achieve and has generated numerous theoretical debates. ${ }^{59}$

In turn, these vagaries of CIL create space for such narratives as those surrounding the UDHR and the UNDRIP which mutually do violence to the concept of customary law. Simma and Alston note that the overarching narrative which posits that the UDHR is part of CIL generates an identity crisis in the concept. Specifically, it promotes the idea that in the formation of CIL, state practice no longer has a constitutive role to play; rather it now serves only an evidentiary function. ${ }^{60}$ This view promotes opinio juris as the constitutive element of CIL which can manifest almost instantly in the communications of international bodies without the burdensome requirement of actual state practice. ${ }^{61}$ Further, this narrative allows the concept of practice itself to undergo what Simma and Alston describe as a "dubious metamorphosis" in that practice has been altered from something that happens in the "real world", such as through the acts of diplomats and delegates, into "paper practice" where the words, texts, votes and excises themselves constitute practice. ${ }^{62}$ In effect, it allows a declarative process to transform into a constitutive process. At the root of this ploy, what is said about behaviour is constitutive of behaviour. ${ }^{63}$ The cumulative effect is that this narrative does violence to CIL but through its prism we can view the UDHR or any declaration as CIL no matter how widespread or persistent the nonconforming state practice.

A similar violence has been perpetrated by the UNDRIP narrative by academics and advocates for Indigenous Peoples through playing fast and loose with CIL. For instance, Anaya and Wiessner's approach to the UNDRIP requires them to portray votes against the UNDRIP (in particular the negative votes of the prominent CANZUS settler state group) in the best possible light by focusing on their participation in the process of drafting the UNDRIP. ${ }^{64}$ This is reminiscent of what Simma and Alston note in relation to the UDHR narrative in which Kiss proposes "if a rule or principle is universally proclaimed and recognized, evidence of its violation is simply irrelevant". ${ }^{65}$ In effect, discrepancies between what is said and what the facts proclaim no longer matter in the creation of CIL, according to these narratives. In terms of the formation of CIL this is significant; it undercuts the importance of state practice as a constitutive element of customary law formation. This has

\footnotetext{
59 The Restatement (Third) of the Foreign Relations Law of the United States enters the waters of this debate offering that "[p]erhaps the sense of legal obligation came originally from principles of natural law or common morality, often already reflected in principles of law common to national legal systems" and "practice built on that sense of obligation then matured into customary law". Or "[p]erhaps the definition reflects a later stage in the history of international law when governments found practice and sense of obligation already in evidence, and accepted them without inquiring as to the original basis of that sense of legal obligation". Restatement (Third) of the Foreign Relations Law of the United States $\S 102$ n. 2 (1987) (citations omitted).

${ }^{60}$ Simma and Alston, supra note 4, p. 89.

${ }^{61} I d$.

${ }^{62} \mathrm{Id}$.

${ }^{63}$ J. d'Aspremont, 'Customary International Law as a Dance Floor: Part 2', ejiltalk.org, available at <www.ejiltalk.org/customary-international-law-as-a-dance-floor-part-ii/> visited 15 April 2014.

${ }^{64}$ Allen, supra note 40, p. 230.

${ }^{65}$ Simma and Alston, supra note 4, p. 82. See also F. Krigis, 'Custom on a Sliding Scale', 81 AJIL (1987) p. 146 in Simma and Alston, supra note 4, p. 96. ("[T]he Universal Declaration of Human Rights has come to be regarded as an authoritative articulation of customary international law, at least with respect to the most prominent fundamental rights, no matter how widespread or persistent the nonconforming state conduct may be.") (Emphasis added.)
} 
been most evident in relation to the UNDRIP where evidence has focused instead on that discernible from international instruments, reports and decisions by authoritative international bodies, such as the UN Commissions/Committees and those of regional human rights commissions and courts. ${ }^{66}$

This approach to discover practice involves moving away from the self-generating character of CIL; in effect moving away from the idea that CIL is generated by state practice and beliefs at all and looking towards the practice of third parties, even if this practice is virtual. ${ }^{67}$ Collectively then, these narratives contribute to double counting techniques. Simma and Alston note in relation to the UDHR narrative that de-emphasizing the role of state practice as a constitutive element of CIL comes with a tendency to count the articulation of a rule twice; ${ }^{68}$ that is double counting not only as opinio juris but also as state practice. Similarly, the UNDRIP's narrative is dependent on double counting - where a piece of evidence is interpreted as both opinio juris and state practice. ${ }^{69}$

In turn, while it has been noted that the UDHR and the UNDRIP may have significant effects on the formation of CIL ${ }^{70}$ this observation is in relation to the substance of CIL. However, the aforementioned violence of both these narratives reveal that they also have significant effects on the formation of CIL itself, which is an observation in relation to its very structure. At the core of this violence, is placing too much weight on the opinio juris component of CIL and distorting what remains of 'state' practice. Post Simma and Alston, this has come to be known as the "modern approach to making CIL" "71 and its sophistication lies not in distinguishing these elements of CIL but in construing them as "two elements of the same dialectical process, if not two faces of the same coin". ${ }^{72}$ In effect, the idea here is that the benefit of such an approach is that focusing on this subjective element of what states think the law is or should be is preferable as not all states have the capacity to engage in practice across substantive areas of international law. In turn, it can be viewed as the democratization of CIL as it allows all states to participate in CIL making. Furthermore, it increases the pace at which CIL can be made, which is beneficial as it allows international law to respond to our fast-paced globalized modern world which often outruns the notoriously slow treaty making process. While prima facie there is nothing problematic with these developments and indeed these are laudable ends, we remain encumbered with the issues of the inherent circularity of reasoning in opinio juris. ${ }^{73}$ However, even more concerning is the fact that international law lacks the structure to aid in the identification of CIL on the basis of opinio juris alone. Without such a structure in place, the creation of CIL under this modern approach can easily fall victim to politics and instrumentalist demands where this violence is vindicated on the grounds of the international legal project: the development of international law for the benefit of individuals and now collective rights.

In turn, this manipulation of CIL by both the UDHR and UNDRIP narratives lays bare the ever-present political context in which international and in particular human rights law operates. In effect, the UDHR and UNDRIP narratives remind us of the political

\footnotetext{
${ }^{66}$ Allen, supra note 40, p. 232 (citations omitted).

67 d'Aspremont, supra note 63.

${ }^{68}$ Simma and Alston, supra note 4, p. 96.

${ }^{69}$ Allen, supra note 40, p. 232.

70 This is the fons et origo narrative within human rights law. See supra notes 54 and 55 .

${ }^{71}$ A. Roberts, 'Traditional and Modern Approaches to Customary International Law: A Reconciliation', 95 American Journal of International Law (2001) p. 757.

72 d'Aspremont, supra note 63.

${ }^{73}$ See supra note 53 and accompanying text.
} 
underpinnings of IHRL as the predominate lingua franca of the moral paradigm of the late twentieth and early twenty-first centuries. While politics usually operates to the detriment of human rights, these narratives recognize and embrace CIL in the quest for the promotion and protection of human rights at the expense of its intrinsic components to achieve the desired policy outcome of binding IHRL. However, it comes at the expense of the traditional understanding of CIL as a source of international law paying only lip-service to its requirement of state practice. And who is it that is only paying this lip-service to CIL? Academics, activists and international lawyers alike who take advantage of these vagaries of CIL for our own instrumentalist ends ${ }^{74}$ and in doing so expand the acceptable parameters of $\mathrm{CIL}$ as accepted in international law.

In particular, this expansionism for instrumentalist ends within international law has been most developed by the international legal project where "the latest generation of international lawyers and scholars are typically committed to a vision of 'the international' in which international law and its concomitant institutions are seen as forces for good". ${ }^{75}$ By contrast, states are seen as bad and so they need to be forced into doing the right thing. ${ }^{76}$ This project is made manifest in many facets of international law including IHRL, international humanitarian law (IHL) and international criminal law (ICL) where a trend towards humanization began post-World War II. It offers that in light of atrocities of World War II, in particular the loss of civilian life, there needed to be a readjustment to the state-centric focus of international law. ${ }^{77}$ Indeed, what Simma and Alston identify in relation to the UDHR as early as 1946 is an example of this humanization in IHRL. It continues today in relation to the UNDRIP through the work of academics and advocates for indigenous rights. Since then international law has been undergoing a paradigmatic shift, moving from focus on the relationship between states towards a focus on the relationship between states and their treatment of individuals at the expense of traditional understandings of sovereignty. The principles that underpin this humanization of international law have led to this violence against CIL in order to increase the promotion and protection of human rights. Fuelled by globalization and cosmopolitanism, this instrumentalism has been observed within the context of IHRL.

In IHRL, scholarship and practice, customary international law has proved the most popular law-ascertainment instrument when it comes to stretching the scope of IHRL and "discovering" new rules for the protection of individuals. It is as if anything that cannot be supported by treaties and which is deemed desirable can, with a bit of effort and creativity, be found in customary law. The reason for the success of custom is not difficult to fathom. Its greater departure from formal modes of legal reasoning provides a less constrained argumentative space and this is why it has been deem "irresistible" for human rights lawyers. ${ }^{78}$

The aim of the international legal project is praiseworthy as it seeks to increase the promotion and protection of human rights to even the most vulnerable populations such as Indigenous Peoples. Indeed, the law that is being produced through these questionable techniques is

\footnotetext{
${ }^{74}$ See J. d'Aspremont, 'Expansionism and the Sources of International Human Rights Law', 46 Israel Yearbook of International Human Rights (2016) p. 223; J. d'Aspremont, 'The Decay of Modern Customary International Law in Spite of Scholarly Heroism', Global Community: Yearbook of International Law and Jurisprudence (2015) (discussing this instrumentalists approach in relation to CIL).

75 Allen, supra note 40, p. 226 (citations omitted).

${ }^{76} I d$., p. 226.

${ }^{77}$ See M. Hakimi, 'Custom's Method and Process: Lessons from International Humanitarian Law', in C. Bradley (ed.), Custom's Future: International Law in a Changing World (Cambridge: CUP, 2016).

78 d'Aspremont, 'Expansionism' supra note 74, p. 223.
} 
undoubtedly a positive development within the international legal system, such as the creation of a discrete segment for the protection of Indigenous rights. However, it comes at a price; the price of the structural integrity of international law. Not only does it do violence to $\mathrm{CIL}$, from a more systemic perspective, in the long run this violence ultimately separates the creation of international law from the consent of states. This risks decreasing the perceived legitimacy of the entire international legal system. How? Well, as mentioned, the violence that it does involves removing state practice. When legal obligations are imposed without roots in the consent of states to be bound, it does not matter how well intentioned the aims are of the politics of the international legal project as this compromises a foundational principle in the international legal order: legitimacy. The knock on effect is decreased confidence in international law and its respect for sovereignty and territorial integrity. So the strategy here is rather short-sighted. The immediate and laudable gains come at the expense of the longterm stability and the very foundations of the international legal order: legitimacy, or at least perceived legitimacy. Ultimately, this landscape of politics in which human rights operates is also evident in a further narrative surrounding the UNDRIP; the 'no new rights narrative'.

\section{Divergence: Indigenous Peoples \& Human Rights}

In contrast to the UDHR, advocates of the UNDRIP also have created another narrative, the 'no new rights' narrative. Advocated simultaneously in relation to the UNDRIP, it is through this account that academics and advocates have moved beyond the CIL narrative and that the essentialization of indigenous claims by the human rights discourse is made manifest; both of which contribute ultimately to the poor enforcement of the UNDRIP.

The 'no new rights' narrative starts with the premise that the UNDRIP contains no new rights and is widely promoted by academics and advocates. The UN Permanent Forum on Indigenous Issues (UNPFII) explains that the UNDRIP, "[r]ather ... provides a detailing or interpretation of the human rights enshrined in other international human rights instruments of universal resonance - as these apply to indigenous peoples and indigenous individuals". ${ }^{79}$ On the adoption of the UNDRIP, Les Malezer, Chairperson of the Global Indigenous Caucus, noted that "[i]t contained no new provisions of human rights. It was based on rights that had been approved by the United Nations system but which had somehow, over the years, been denied to indigenous peoples." ${ }^{80}$ Similarly, S. James Anaya, early after the adoption of the UNDRIP, stated that:

[t]he Declaration does not affirm or create special rights separate from fundamental human rights that are deemed of universal application, but rather elaborates upon fundamental rights in the specific cultural, historical, social and economic circumstances of indigenous peoples. These include the basic norms of equality and non-discrimination, as well as other generally applicable human rights in areas such as culture, health or property which are recognized in other international instruments and are universally applicable. ${ }^{81}$

\footnotetext{
${ }^{79}$ United Nations Permanent Forum on Indigenous Issues, FAQs, (2012) at <undesadspd.org/indigenouspeoples. aspx>.

${ }^{80}$ L. Malzer, 'Statement', at <www.un.org/News/Press/docs/2007/ga10612.doc.htm>. Malezer reaffirmed his commitment to this position with the author in discussions at the Institute for Commonwealth Studies Conference in September 2013. Institute of Commonwealth Studies, School of Advanced Study, University of London, ICWS Conference, September 2013 (notes on file with author).

${ }^{81}$ S.J. Anaya, The Human Rights of Indigenous Peoples in Light of the New Declaration, and the Challenge of Making Them Operative, Report of the Special Rapporteur on the situation of human rights and fundamental freedoms of indigenous peoples, UN Doc. A/HRC/9/9,5 at para. 38 (August 2008). See also M. Barelli, supra note 19 ("First, the Declaration may be regarded as evidence of existing law.").
} 
Typically, when making a new human rights claim there are two stages put forward by the claimant. ${ }^{82}$ First, the claimant emphasizes that the new right at least in part embodies the broader general characteristics of human rights such as respect for dignity and equality. The claimant then advocates the new right's unique and particular component. Indigenous claims in the human rights discourse through the 'no new rights' narrative replicates the first stage of this process but ignores that second stage. In the contrary, the 'no new rights' narrative substitutes advocating what is unique about the right with the view of the "elaboration of general human rights as an interpretative act rather than as a means for the creation of new rights" ${ }^{83}$ Specifically, it serves "an interpretative function in that it makes the UNDRIP a lens through which to view and apply fundamental human rights in the indigenous context in either customary or treaty law". ${ }^{84}$ Thereby the 'no new rights' narrative promotes the idea that the status of the UNDRIP as a source of law is irrelevant.

This is significant. This 'no new rights' narrative removes the UNDRIP from the specific CIL narrative but not from the broader sources of law discourse. In turn it avoids violence to CIL as a result of this removal. However, the reality is that the 'no new rights' narrative is still concerned with legal logic of the sources of international law discourse. Indeed both narratives coalesce around the legal logic of the broader sources of international law discourse. The former CIL narrative simply expresses this logic directly, working to locate elements of state practice and opinio juris; while this 'no new rights' narrative expresses this logic indirectly noting that it does not matter that the UNDRIP is not binding hard law because as soft law it can achieve the same end. However, this leaves the question: what 'end' is this? In effect, both narratives as part of the broader sources of international law discourse ultimately seek to ensure the 'end' of the implementation of rights; albeit human rights or more specifically indigenous rights. Indeed, international law requires that a declaration such as the UNDRIP is "characterized by a satisfactory degree of effective compliance by States". ${ }^{85}$ Consequently, as regards indigenous rights, both the CIL narrative and the 'no new rights' narrative make apparent a fundamental tension; a tension between declaring that there exist solid international norms and serious problems of implementation. As the ILA Committee on the Implementation of the Rights of Indigenous Peoples notes, at this stage its work reveals that effective implementation of indigenous rights, in particular at the executive and administrative levels, is unsatisfactory. ${ }^{86}$ These implementation problems undermine the idea or the assertion that indigenous rights are international law and both narratives are a way to circumvent the fact that there has not been much state practice. In turn, both narratives are not good strategies to ensure the enforcement of the UNDRIP. ${ }^{87}$

In particular, the 'no new rights' narrative contributes to poor enforcement as it is an essentialist strategy. Specifically, the 'no new rights' narrative reflects the essentialism that the human rights discourse demands of Indigenous Peoples. Claiming new human rights should appeal to Indigenous Peoples as it offers them access to a rights discourse which hitherto they have been denied, thereby internationalizing their struggle and moving them

\footnotetext{
${ }^{82}$ Allen, supra note 40, p. 236 as identified by K. Gunther, 'The Legacies of Injustice and Fear: A European Approach to Human Rights and their Effects on Political Culture', in P. Alston (ed.), The EU and Human Rights (1999) p. 136.

${ }^{83}$ Allen, supra note 40, p. 236.

${ }^{84}$ Allen, supra note 40, p. 231.

${ }^{85}$ Lenzerini, supra note 39, p. 55.

${ }^{86}$ Id., p. 59.

${ }^{87}$ See Allen, supra note 40, p. 253.
} 
into the international community. ${ }^{88}$ However, moving into the human rights discourse simultaneously constrains the claims of Indigenous Peoples by demanding a static and essentialized notion of indigenous culture. ${ }^{89}$ The 'no new rights' narrative is an example of such essentialism. Specifically, in ignoring this second stage of advocating what is unique about the right, the 'no new rights' narrative avoids stirring up identity politics ${ }^{90}$ and raising the spectre of special privilege or special rights. In effect, the 'no new rights' narrative erases the colonial history of indigenous claims. This reflects the essentialism of the human rights discourse which is not directly geared towards addressing the ills of colonialism and its vestiges though these vestiges continue to affect the realities of Indigenous Peoples. Rather, the focus of human rights law is on the recognition, promotion and protection of human rights.

Generally speaking, rights, and in particular human rights, work to trump politics and utilitarian and realist assessments regarding good. ${ }^{91}$ They mask the subjectivity of claims through their objective presentation ultimately transforming political desires into the lingua franca of human rights. ${ }^{92}$ In turn, the essentialism of the human rights discourse constrains the claims of Indigenous Peoples and promotes advocacy strategies that follow suit. Specifically, the 'no new rights' narrative is an example of such an essentialized strategy. Similar to other essentialist strategies, it demands that indigenous rights advocates make concessions which work to exclude many claimants and/or force them into norms of cultural cohesion. ${ }^{93}$ Ultimately then, the indigenous advocacy of the 'no new rights' narrative fits more comfortably within the human rights discourse as it allows Indigenous Peoples the opportunity to transpose their claims as colonized peoples into the language of human rights law. It is this transposition to accommodate the human rights discourse that results in the essentialization of indigenous claims.

In turn, with a strategy such as the 'no new rights' narrative, the potential exists for its essentialist claims to no longer be reflective of reality. Without roots in reality, indigenous claims are perceived as weak, which contributes to poor enforcement. First, the story embodied in the 'no new rights' narrative does not reflect the reality that the UNDRIP offers sui generis rights. Sui generis rights are not rights derived from a positive legal system but rather in the case of Indigenous Peoples "arise sui generis from the historical condition of indigenous peoples as distinctive societies with the aspiration to survive as such". ${ }^{94}$ In particular, "disenfranchised groups have traditionally benefitted from asserting their legal rights. By asserting legal rights, minority groups gain inclusion and power within a legal system that has historically excluded and oppressed them." 95 In turn, rather than reflecting reality, this approach of the 'no new rights' narrative and so the denial of the sui generis

\footnotetext{
${ }^{88}$ Allen, supra note 40, pp. 235-236.

${ }^{89}$ See generally Engle, supra note 9.

${ }^{90}$ Allen, supra note 40, p. 236.

${ }^{91}$ Allen, supra note 40, p. 235 citing M. Koskenniemi, 'The Effect of Rights on Political Culture', in P. Alston (ed.), The EU and Human Rights (Oxford: OUP, 1999) p. 101.

$92 \mathrm{Id}$.

${ }^{93}$ See generally K. Engle, supra note 9 (generally discussing the effects of essentialism on indigenous advocacy in the space of human rights).

${ }^{94}$ H. Berman, 'Are Indigenous Populations Entitled to International Juridical Personality?', 79 American Society of International Law Proc. (1989) p. 193 reprinted in J. Gilbert, 'Indigenous Rights in the Making: The United Nations Declaration on the Rights of Indigenous Peoples', 14 International Journal on Minority and Groups Rights (2007) pp. 207, 210.

${ }^{95}$ R. Tsosie, 'Privileging Claims to the Past: Ancient Human Remains and Contemporary Cultural Values', 31 Arizona State Law Journal (1999) p. 661.
} 
nature of the rights in the UNDRIP seems more a politically savvy strategy; a strategy rooted in the implicit acknowledgement that such claims would have endangered the adoption of the UNDRIP and reminiscent of the aims of the international legal project. Specifically, the story embodied in this narrative of 'no new rights' is an advocacy strategy to gain state support as it allows Indigenous Peoples to achieve two political advantages. First, this approach allows Indigenous Peoples to stress that "universal, unhistorical and unpolitical nature of the rights contained in the Declaration, thus hiding their particular, temporal and political characteristics". ${ }^{96}$ Secondly, this approach allows advocates to avoid "stirring up identity politics". ${ }^{97}$

Moreover, the essentialization of indigenous claims presents a disjuncture between indigenous claims and the lived experience of Indigenous Peoples. The essentialization of indigenous claims through the 'no new rights' narrative presents a story that erases the colonial context of indigenous claims. Yet the lived experiences of Indigenous Peoples and the root of their claims stem from their colonial pasts. In effect, this disjuncture does not reflect the lived realities of Indigenous Peoples. This is then exacerbated by the fact that while human rights might deliver some gains to Indigenous Peoples, these gains have not been substantial in many areas in affecting change in the lived realities of Indigenous Peoples. ${ }^{98}$ Indeed, the success of this strategy depends on the extent to which decision makers including states, courts or other institutions are persuaded by this approach. This leaves the operationalization of the UNDRIP on fragile ground and it is by no means guaranteed. ${ }^{99}$ Hence, the contribution of the 'no new rights' narrative to the poor enforcement of the Declaration and the development of a second strategy asserting that the Declaration merely reflects existing CIL. ${ }^{100}$

\section{Some Conclusions: Looking Forward Looking Back}

Palais des Nations, we have problem. Outside of these walls, ${ }^{101}$ international lawyers, academics and activists have been perpetrating and continue to perpetrate violence against the concept of CIL in ways that are unsustainable and detrimental in the long run to the very foundations of the international legal order. "All-in-all, the intellectual prison of custom seems to be gradually transformed into a large dance floor where almost every step and movement is allowed or, at least, tolerated."102 This transformation has been enabled by both the perfect storm of the vagaries of CIL and the drive of the international legal project and its laudable ends of securing the promotion and protection of individual and more recently collective human rights. Moreover, the storm that it has generated is not in a teacup. Its short-term gains of academic freedom and democratization of international law-making comes at the expense of the very foundation of the international legal order by undermining long-term legitimacy through the removal of consensual state-based law-making. In addition, the tone on the dancefloor of creativity in unbinding CIL from its foundations is not "necessarily that of flower people or that of tolerance" but that which is dogmatic and assertive where everything can be said about CIL, but anything hostile to this new academic

\footnotetext{
${ }^{96}$ Allen, supra note 36, p. 236.

${ }^{97}$ Id.

98 See Lenzerini, supra note 39, p. 55.

${ }^{99}$ Allen supra note 40, p. 231.

${ }^{100}$ See supra Section 2.2 (discussing the UNDRIP customary law narrative).

101 As d'Aspremont notes with praise, inside the walls of the Palais de Nations there is a "welcome pragmatism" displayed by the Special Rapporteur of the International Law Commission, Sir Michael Wood, who has sought self-restraint in relation to its work to identify CIL. d'Aspremont, supra note 3.

102 d'Aspremont, supra note 63.
} 
freedom is not tolerated. ${ }^{103}$ In turn, suggesting let alone implementing change faces significant hurdles which is borne out by the fact that this violence and the problems it generates are not new. Indeed, they are well entrenched if not intrinsic to modern international law-making.

Exploring the convergent and divergent threads emerging from a critical analysis of the UNDRIP in light of the UDHR demonstrates that the narrative of the former simply perpetuates the violence to CIL and the international legal order within the indigenous rights movement. Specifically, it replicates the narrative of the UDHR which dates back to its inception in 1948 motivated by a strong desire to prevent atrocities in the recent wake of World War II. In effect, the historical debate surrounding the legal status of the UDHR has paved the way for the construction of this narrative within the context of indigenous rights in the early twenty-first century; looking forward to securing the promotion and protection of indigenous rights by looking back to the UDHR. In turn, the problems identified by Simma and Alston over a quarter of a century ago in relation to CIL in human rights law have been replicated by academics and advocates for Indigenous Peoples in the creation of a discrete framework for the protection of indigenous rights within the human rights framework.

Yet given its varying trajectory of securing indigenous rights, advocates of the UNDRIP went beyond the CIL narrative and its focus on the soft law versus hard law dichotomy and produced a new narrative; that of 'no new rights'. While this 'no new rights' narrative does not perpetuate direct violence against CIL, it is still bound by the legal logic of the broader sources of international law discourse which ultimately works to ensure the implementation of rights. Indeed, both the convergent and divergent discourses presented herein, however misguided, aim to ensure the goal of implementation of human rights and in doing so reveal a fundamental tension between declaring that there exist solid international norms and serious problems of implementation. Particularly in the case of indigenous rights and the UNDRIP, this poor implementation is exacerbated by the fact that the 'no new rights' narrative is bound by the essentialism characteristic of the human rights discourse and its approach to Indigenous Peoples. At the expense of hybrid and evolving identities, the essentialism of the 'no new rights' narrative renders claims that are no longer reflective of the realities of Indigenous Peoples in erasing their colonial experiences in order to avoid identity politics and the spectre of special privileges and rights. In turn, such a disjuncture between indigenous claims and indigenous realities when presented within a context where limited gains have been made forces us to at least question both the usefulness of approaching the promotion and protection of indigenous rights though human rights law and the political savvy of this divergent strategy.

Ultimately, exploring this question of violence and unsustainability regarding CIL and its role in the international legal order has come to the fore again as a result of the International Law Commission Report on CIL. ${ }^{104}$ However, it is now more complicated than when Simma and Alston first noted these issues. Given the proliferation of non-state actors in international law, including Indigenous Peoples who may have different aims and trajectories for human rights, this allows not only for the violence perpetrated against CIL to continue but for the proliferation of other narratives to surround the broader sources of law discourse; narratives which further undermine legitimacy and implementation. In turn, now more than ever this pressing problem must be addressed but undoubtedly this is easier said than done.

\footnotetext{
${ }^{103} I d$.

${ }^{104}$ See d'Aspremont, supra note 3.
} 
